\title{
Some Factors Influencing the Rate of Formation of Tetrathionase
}

\author{
By W. H. H. JEBB, R. KNOX AND A. H. TOMLINSON \\ Public Health Laboratory, Oxford
}

\begin{abstract}
SUMMARY: The intermediate type I coliform organism 1433 can use, as hydrogen donators during the adaptive formation of the tetrathionase enzyme system, most of the carbohydrates that it can ferment, although in some cases the cells must first be grown on a medium containing the carbohydrate concerned. Not only the reduction of tetrathionate, but the process of adaptive formation of tetrathionase as well, is inhibited by oxygen gas, but the capacity to adapt when favourable conditions are restored is relatively unaffected by oxygen. The amount and the rate of formation of new enzyme are greatly increased by providing a source of available nitrogen. The rate of formation is also increased by incubating the cells with mannitol and phosphate before tetrathionate is added, but the total amount of enzyme formed is not increased: it is probable that the increased rate is due to the accumulation of intermediates within the cells; these intermediates have not so far been identified. None of the mathematical expressions investigated fits the course of tetrathionase adaptation exactly; that put forward by Spiegelman (1945) for the production of yeast galactozymase approximates most closely.
\end{abstract}

Knox \& Pollock (1944) described in the Salmonella and Proteus groups and in certain coliform organisms an adaptive enzyme system which reduced tetrathionate quantitatively to thiosulphate. This adaptation occurred in washed suspension, in the absence of a nitrogen source and without demonstrable increase in cell numbers or cell material. The effect of certain alterations in the composition of the suspending fluid was also investigated, and Pollock (1945) described the effect of temperature on tetrathionase adaptation.

Gale (1943) reviewed the factors influencing the activity of bacterial enzymes, and Monod (1947) described the particular characteristics of 'adaptation', which he defined as 'apo-enzyme formation induced by a specific substrate'. The evidence for the production of a new enzyme is often largely circumstantial, but in the case of yeast galactozymase various workers (Kosterlitz, 1943; Spiegelman, Reiner \& Morgan, 1947; Wilkinson, 1949) have presented convincing evidence of the presence of a new enzyme in the adapted cells. The results of the present investigation are interpreted on the assumption that new enzyme is formed; the evidence for this will be discussed later.

In this investigation an attempt was made to find a mathematical expression for the rate of enzyme production and to test its agreement with Spiegelman's theory of enzyme formation (Spiegelman, 1945). In addition, the effects of oxygenation, an added nitrogen source, and pre-incubation of the cells with mannitol and phosphate, have been studied in an attempt to reach a fuller understanding of the adaptive process. 


\section{METHODS}

Organism. The organism used was the coliform intermediate type I labelled ' 1433 ' used by Knox, Gell \& Pollock (1943) in their work on the selective action of tetrathionate, and subsequently by Pollock (1946), Pollock \& Wainwright (1948) and Jebb (1949).

Preparation of suspensions. All suspensions were prepared by inoculating $1 \mathrm{ml}$. of a $6 \mathrm{hr}$. tryptic heart broth culture on to $200 \mathrm{ml}$. tryptic heart agar in Roux bottles. The Roux bottles were incubated at $37^{\circ}$ for $15-17 \mathrm{hr}$. and the cells washed off with distilled water. The cell suspension was centrifuged, the cells washed twice with distilled water and made into a thick suspension in water. The cell suspension was adjusted, using a Hilger Biochem Absorptiometer, to contain 12-14 mg. dry weight/ml.; this was the stock cell suspension.

Adaptation experiments. Unless otherwise stated, the following final concentrations were used in adaptation reaction mixtures: stock cell suspension

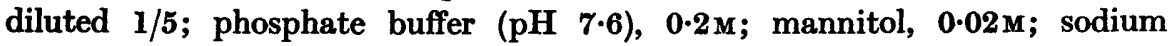
tetrathionate, $0.02 \mathrm{M}$. Samples were removed at intervals and mixed with twice their own volume of $10 \%(v / v)$ aqueous acetic acid to which a few drops of $0.5 \%$ starch were added, and titrated with $0.005 \mathrm{~N}$ iodine.

Sodium tetrathionate was prepared by the method described by Gilman, Phillips, Koelle, Allen \& St John (1946).

Temperature. All the experiments were carried out at $37^{\circ}$.

\section{RESULTS}

The nature of the hydrogen donator

Of the common 'sugars' used in diagnostic bacteriology the organism 1433 ferments glucose, fructose, galactose, maltose, lactose, arabinose, xylose, sorbitol, mannitol and glycerol. With the exception of xylose, all of these acted as hydrogen donators for rapid adaptation, though galactose, lactose, maltose, arabinose and sorbitol could be so utilized only by cells previously grown on media containing the compound concerned. The enzymes attacking these latter compounds are presumably adaptive.

Other substances which could be dehydrogenated by the enzymes of the cell, namely lactate, formate, succinate and ethanol, could supply hydrogen for reduction of tetrathionate by adapted cells, but did not stimulate a rapid adaptation of fresh cells. Hence the hydrogen donator for rapid adaptation in washed suspension must be fermentable.

\section{Measurement of tetrathionase activity}

To study the adaptive process in detail it was desirable to determine the tetrathionase activity at various times during the process. This involved measuring the rate of reduction of tetrathionate by partially adapted cells under conditions where further adaptation could not occur. This could be done by using formate or lactate as hydrogen donator, or by inhibiting adaptation in the presence of mannitol by $2: 4$-dinitrophenol or sodium azide. 
The choice of a suitable method presented some difficulty. Table 1 shows that the activity of tetrathionase as measured by the rate of reduction was dependent on the hydrogen donator used and also on the activity of the dehydrogenating system-as shown by the variation in relative rates with different $\mathbf{H}$ donators in different experiments. The stimulation of reduction by the dinitrophenol appears similar to its effect on the oxygen uptake of Bact. coli (Clifton, 1946) and of frog muscle (Ronzoni \& Ehrenfest, 1936).

Table 1. Rates of reduction of tetrathionate by fully adapted cell suspensions of organism 1433 in the presence of various hydrogen donators

(Tubes contained (final concentrations): adapted cell suspension 1/10, phosphate buffer (pH $7 \cdot 6) 0.2 \mathrm{M}$, sodium tetrathionate $0.02 \mathrm{M}$ and the hydrogen donator in the concentration indicated.)

$\left.\begin{array}{l}\begin{array}{c}\text { Hydrogen donator } \\ \text { or other addendum } \\ \text { (final concentration) }\end{array} \\ \text { Mannitol, } 0.02 \mathrm{M} \\ \text { Dinitrophenol, } 0.0005 \mathrm{M}\end{array}\right\}$

\begin{tabular}{|c|c|c|}
\hline Exp. 1 & Exp. 2 & Exp. 3 \\
\hline $18 \cdot 6$ & $31 \cdot 8$ & - \\
\hline $17 \cdot 7$ & $25 \cdot 9$ & $19 \cdot 3$ \\
\hline $17 \cdot 2$ & $29 \cdot 0$ & $25 \cdot 1$ \\
\hline $16 \cdot 8$ & $25 \cdot 4$ & $18 \cdot 9$ \\
\hline $6 \cdot 4$ & $10 \cdot 4$ & $15 \cdot 1$ \\
\hline
\end{tabular}

Fig. 1 shows the rates of reduction of tetrathionate, as determined with different hydrogen donators, at different stages of adaptation. From the figure it can be seen that mannitol with dinitrophenol gave the highest rate, but this combination was considered unsuitable because the graph crossed the lactate curve, suggesting that the dinitrophenol stimulation increased with time of adaptation. Formate was not considered suitable because during adaptation in the presence of heart broth formic hydrogenlyase was produced (as shown by Warburg respirometer experiments) and, while this may be irrelevant, it was thought wiser to avoid unnecessary complications. Organism 1433 possesses a hydrogenase, and gaseous hydrogen, in the Warburg respirometer, was tried as a hydrogen donator but proved unsatisfactory because of the high blank reduction. The hydrogen uptake accounted for only $60 \%$ of the tetrathionate reduced. Sodium lactate was eventually chosen as a hydrogen donator because it appeared to reveal a high proportion of the tetrathionase activity of all suspensions and it was not open to the above objections.

The method finally adopted for estimating the tetrathionase activity, which we define as the rate of reduction under standard conditions, was the following:

$10 \mathrm{ml}$. samples were removed from the adaptation mixtures, cooled rapidly, centrifuged, washed twice in distilled water, suspended in a small volume of water and added to $2 \mathrm{ml}$. $\mathrm{M}$ phosphate buffer ( $\mathrm{pH} \mathrm{7 \cdot 6}$ ), $1 \mathrm{ml}$. sodium lactate $0.5 \mathrm{M}$, and $1 \mathrm{ml}$. sodium tetrathionate $0.2 \mathrm{M}$, and made up to a volume of $10 \mathrm{ml}$. Samples were titrated with iodine as described previously, and the tetrathionase activity expressed in terms of $\mu \mathrm{mol}$. thiosulphate produced $/ \mathrm{mg}$. dry wt. cells/hr. 


\section{Adaptation under standard conditions}

The course of tetrathionate reduction by adapting cells is shown in Fig. 2. The increase of activity with time is shown by curve $(a)$ of Fig. 3 . To facilitate comparison of adaptations under different conditions it seemed desirable to obtain an equation which would represent the adaptation process, and provide a measure of the rate of enzyme production.

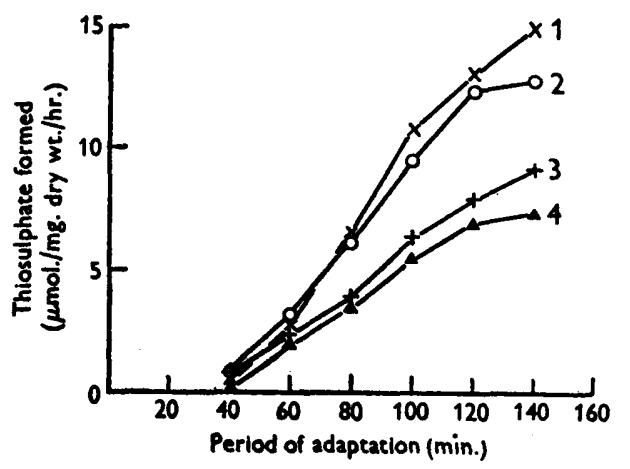

Fig. 1

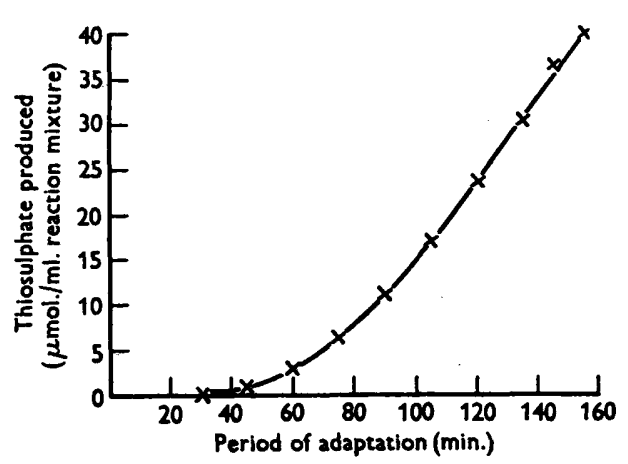

Fig. 2

Fig. 1. Tetrathionase activities determined with different hydrogen donators after various periods of adaptation in standard reaction mixture. Each assay tube contained: 2 ml. cell suspension; $2 \mathrm{ml}$. $\mathrm{M}$ phosphate $(\mathrm{pH} \mathrm{7.6}) ; 1 \mathrm{ml} .0 \cdot 2 \mathrm{M}$ sodium tetrathionate; and in curve $1(x-x), 1 \mathrm{ml}$. 0.2 M mannitol, $0.5 \mathrm{ml}$. 0.01 $\mathrm{m} 2$ :4-dinitrophenol and $3.5 \mathrm{ml}$. water; in curve $2(\mathrm{O}-\mathrm{O}), 1 \mathrm{ml} .0 .5 \mathrm{M}$ sodium lactate and $4 \mathrm{ml}$. water; in curve 3 $(+-+), 1 \mathrm{ml}$. $0 \cdot 2 \mathrm{~m}$ sodium formate and $4 \mathrm{ml}$. water; in curve $4(\Lambda-\Delta), 1 \mathrm{ml}$. 0.4 methanol and $4 \mathrm{ml}$. water.

Fig. 2. Tetrathionase adaptation under standard conditions. Reaction mixture contained: stock cell suspension diluted 1/5; phosphate buffer (pH 7.6), 0.2 M; mannitol, 0.02M; sodium tetrathionate, $0.02 \mathrm{M}$. Samples were removed at intervals and the thiosulphate produced titrated with $0 \cdot 005 \mathrm{~N}$ iodine.

From Fig. 2 it appeared that the process might be represented either by an exponential function or by an equation such as

$$
\text { thiosulphate formed }=\text { constant } \times(\text { time })^{n} \text {, }
$$

where $n$ is 2 or 3. A plot of $\log$ (thiosulphate formed) against time was linear only during the early stages of adaptation. Graphs of thiosulphate formed against the square of time and against the cube of time were each linear during a part of the process, but neither gave agreement over the whole period of adaptation, nor could any of these expressions account for the gradual cessation of adaptation.

Spiegelman (1945) found that the galactozymase adaptation of yeast was adequately represented by the equation

$$
\boldsymbol{E}=\frac{\ddot{\boldsymbol{P}}}{1+e^{a-k t}}
$$

where $E$ is the amount of enzyme present at time $t, \widetilde{P}$ is the amount of enzyme 
finally formed from a precursor $P$, and $a$ and $k$ are constants. This equation can be rearranged

$$
a-k t=\ln \frac{\overline{\boldsymbol{P}}-\boldsymbol{E}}{\boldsymbol{E}}
$$

and the fit of a set of points can be tested by plotting $\log \frac{\overline{\boldsymbol{P}}-E}{E}$ against $t$.

Fig. 4 shows that between 40 and 120 min., the period during which most of the tetrathionase adaptation occurred, the points obtained lay on a straight line, but the point for zero time consistently fell below this line. This dis-

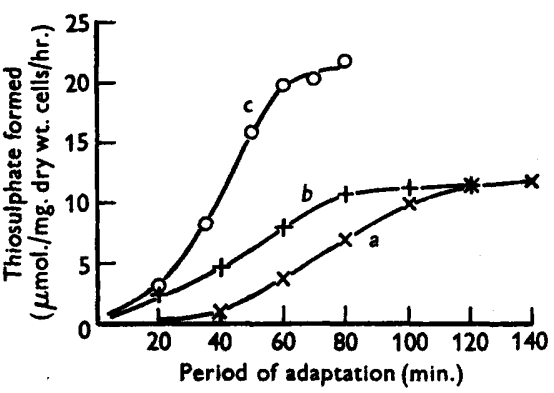

Fig. 3

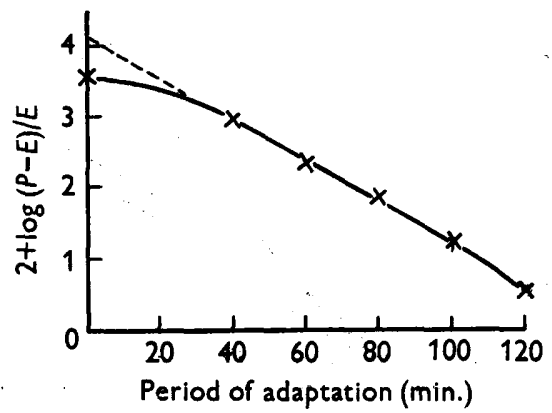

Fig. 4

Fig. 3. Tetrathionase activity during adaptation in solutions of the various compositions described: $20 \mathrm{ml}$. stock cell suspension; $20 \mathrm{ml}$. M phosphate (pH 7.6); $10 \mathrm{ml} .0 .2 \mathrm{M}$ mannitol; $10 \mathrm{ml}$. $0.2 \mathrm{M}$ sodium tetrathionate (all throughout). In addition, in curve $a$ $(x-x),+40 \mathrm{ml}$. water; curve $b(+-+),+40 \mathrm{ml}$. water but in this tube the $10 \mathrm{ml} .0 .2 \mathrm{M}$ sodium tetrathionate was not added until the rest of the mixture had been incubated for $60 \mathrm{~min}$; ; curve $c(\mathrm{O}-\mathrm{O})$, $+40 \mathrm{ml}$ : tryptic heart broth.

Fig. 4. Spiegelman's (1945) formula applied to tetrathionase adaptation. Data calculated from Fig. 3, curve $a$.

crepancy might be due to the determined value of the initial enzyme content being too high, or could be accounted for by a lag during which no adaptation occurred. In a number of experiments the zero-time point $Z$ was regularly 17-20 min. to the left of the line.

Changing the conditions of adaptation (as described later) altered the shape of the $\log \overline{\boldsymbol{P}}-\boldsymbol{E} / \boldsymbol{E}$ time curve, but not in a manner sufficiently consistent to be of any value in comparing adaptations, and it was necessary to fall back on visual comparisons of curves of the type shown in Fig. 3.

It is perhaps relevant to point out that considerable caution is necessary in applying simple mathematical treatments to complex biological phenomena; Monod (1942), for example, has stressed the dangers of such a procedure.

\section{Effect of oxygen on adaptation}

Pollock \& Knox (1943) showed that oxygenation virtually inhibited reduction of tetrathionate by Salmonella paratyphi B, an effect analogous to that of oxygen on nitrate reduction described by Stickland (1931).

Oxygen also inhibits adaptation to tetrathionate reduction. Cells were incubated for $14.5 \mathrm{~min}$. (a) with mannitol, phosphate buffer and tetrathionate; (b) with mannitol, phosphate buffer and tetrathionate and oxygen bubbled 
through continuously; $(c)$ diluted with water to the same dilution as $(a)$ and $(b)$. The cells were then centrifuged off, washed and assayed for tetrathionase. The un-oxygenated cells $(a)$ produced $11.9 \mu \mathrm{mol}$. thiosulphate $/ \mathrm{mg}$. $/ \mathrm{hr}$., whereas the oxygenated cells $(b)$ and the control cells $(c)$ produced $0.24 \mu \mathrm{mol}$. thiosulphate/ mg./hr.

Oxygenation also 'de-adapts' previously adapted cells. Fully adapted cells suspended in $0.05 \mathrm{~m}$ phosphate buffer were oxygenated during incubation at $37^{\circ}$ and at intervals samples were taken out and assayed. Fig. 5 shows the

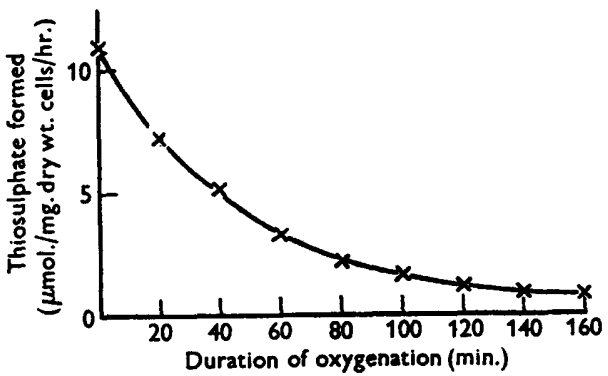

Fig. 5

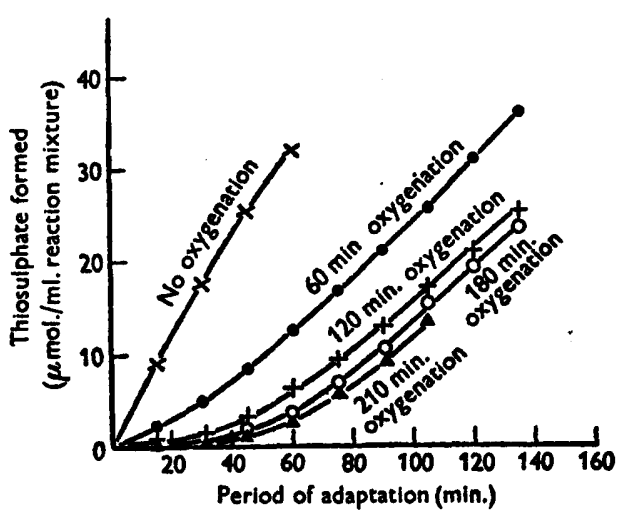

Fig. 6

Fig. 5. Effect of oxygenation on the tetrathionase activity of adapted cells of organism 1433.

Fig. 6. Re-adaptation of previously adapted cells 'de-adapted' by oxygenation for various times. Cells, after oxygenation for various periods (as shown on diagram), were added to a reaction mixture to give the following final concentrations: stock cell suspension diluted 1/5; phosphate buffer (pH 7.6), $0.2 \mathrm{M}$; mannitol, $0.02 \mathrm{M}$; sodium tetrathionate, 0.02 M.

activities of the samples plotted against time of oxygenation. Other samples were put into adaptation mixtures of mannitol, tetrathionate and buffer. From Fig. 6 it can be seen that oxygenation effected a reversible 'de-adaptation', leaving the ability to adapt relatively unimpaired.

Attempts to reactivate such de-adapted cells by incubation in reducing agents such as ascorbic acid, thiolacetate and glutathione were unsuccessful. On the other hand, the presence of tetrathionate during oxygenation did have a slight protective effect and retarded the de-adaptation.

\section{The effect of an added nitrogen source}

Pollock \& Wainwright (1948) showed that the addition of a mixture of amino-acids increased the rate of nitratase adaptation in washed suspensions of the coliform organism 1433. The course of tetrathionase adaptation is markedly changed by supplying to the adapting cells a source of readily available nitrogen. Fig. 3 (curve $c$ ) shows that when $40 \%(v / v)$ of tryptic heart broth was included in the reaction mixture enzyme was produced faster and reached a final activity almost twice that of the same cells without broth (curve a)-an exact parallel to Spiegelman's (1945) observation with yeast 
galactozymase. During adaptation in broth the optical density of the cell suspension increased by about $10 \%$ (of which some could be accounted for by the precipitated sulphur known to be present) but total and viable cell counts showed no increase.

A similar stimulation was produced by casein digest, yeast extract, liver extract and peptone water. A comparison between the following stimulating substances was made by including them in adaptation mixtures namely (a) the laboratory tryptic heart broth; (b) tryptic digest of casein prepared according to Gladstone \& Fildes (1940); (c) an extract prepared by steaming $90 \mathrm{~g}$. minced ox-liver with $30 \mathrm{ml}$. water for $1 \mathrm{hr}$., filtering and adjusting to pH 7.6. The total nitrogen contents of these solutions were determined by the Kjeldahl method and each was then diluted to contain $1.7 \mathrm{mg} . \mathrm{N} / \mathrm{ml}$. These solutions were included in adaptation mixtures of the composition shown in Table 2 which records the results.

\section{Table 2. Effect of different nitrogen sources on the adaptation of organism 1433}

(The added nitrogen sources each contained $1.7 \mathrm{mg} . \mathrm{N} / \mathrm{ml}$. and were added in volumes of $20 \mathrm{ml}$. to the following adaptation mixtures: cell suspension, $10 \mathrm{ml}$.; phosphate buffer (M), $10 \mathrm{ml}$; mannitol, $0.2 \mathrm{M}, 5 \mathrm{ml}$.; tetrathionate, $0.2 \mathrm{M}, 5 \mathrm{ml}$; and nitrogen source, $20 \mathrm{ml}$. (i.e. $40 \%$ of the total volume). At intervals samples of the cells were assayed for tetrathionase activity.)

\begin{tabular}{|c|c|c|c|c|}
\hline & \multicolumn{4}{|c|}{ Added nitrogen source } \\
\hline & None & Liver extract & Broth & Casein digest \\
\hline $\begin{array}{l}\text { Time of } \\
\text { sampling }\end{array}$ & \multicolumn{4}{|c|}{$\begin{array}{l}\text { Tetrathionase activity } \\
\text { ( } \mu \mathrm{mol} . \text { thiosulphate produced/mg. dry wt./hr.) }\end{array}$} \\
\hline 30 & $0 \cdot 2$ & $13 \cdot 5$ & $2 \cdot 5$ & $\mathbf{2 \cdot 3}$ \\
\hline $\mathbf{5 0}$ & $1 \cdot 0$ & $23 \cdot 8$ & $11 \cdot 3$ & $2 \cdot 7$ \\
\hline 70 & $2 \cdot 7$ & $29 \cdot 5$ & $18 \cdot 7$ & $16 \cdot 8$ \\
\hline
\end{tabular}

From the rapidity of adaptation in presence of liver extract it seemed probable that the solution contained specific stimulatory factors. As the optical density of the suspensions increased by $20 \%$ during the adaptation, growth might have been beginning, but total and viable counts did not indicate any significant cell division.

\section{Pre-treatment of cells with mannitol and phosphate}

When cells were incubated at $37^{\circ}$ with mannitol and buffer before tetrathionate was added, the rate of adaptation was increased without affecting the final amount of enzyme produced (Fig. 3, curve $b$ ) in contrast with the effect of an added nitrogen source. This acceleration was produced by pre-treatment with mannitol, glucose or fructose but not with lactate, formate or phosphate alone. The extent of the acceleration depended on the duration of pre-treatment; maximum acceleration was produced by $60-90 \mathrm{~min}$. pre-treatment. It can be seen from Fig. 7 that the linear portions were parallel, that is, the final enzyme activities were equal, but the time taken to reach this rate decreased as the duration of pre-treatment increased. 
Of the possible explanations of this acceleration, the following seemed the most probable: (1) adaptation to mannitol fermentation, which experiments in the Warburg respirometer and on methylene-blue reduction times did not support (see also Pollock, 1946); and (2) the accumulation of some metabolic intermediate or intermediates necessary for adaptation. This postulated intermediate must be in the cells or in the suspending fluid or both, and investigations were carried out in an attempt to determine its location.

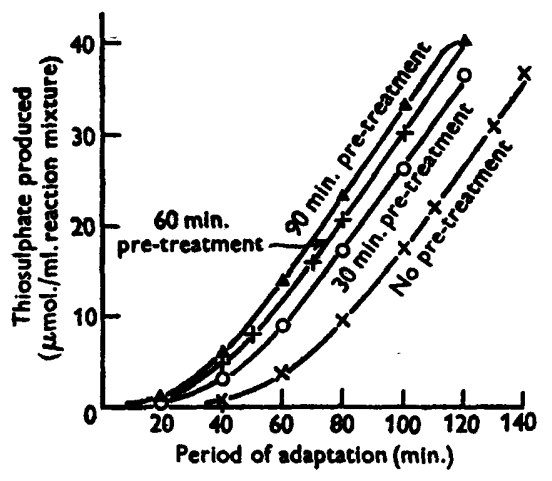

Fig. 7

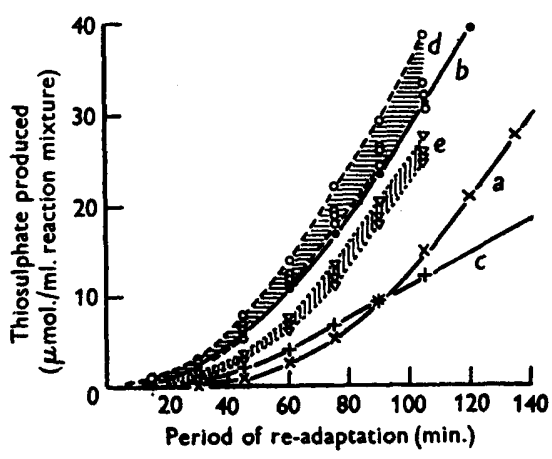

Fig. 8

Fig. 7. Effect of duration of pre-treatment with mannitol and phosphate on the adaptation of washed cells of organism 1433. Each tube contained : stock cell suspension diluted 1/5; phosphate buffer, $0.2 \mathrm{M}$; mannitol, $0.02 \mathrm{M}$; tetrathionate, $0.02 \mathrm{M}$. The tetrathionate was added after the periods of pre-treatment indicated and at intervals samples were removed from each for titration with iodine.

Fig. 8. The change produced in the cells of organism 1433 by pre-treatment with mannitol and phosphate, and the non-specific nature of the changes occurring in the suspending fluid. Curve $a(x-x)$, standard (untreated) adaptation for comparison; curve $b$ (O-O), adaptation after pre-treatment for comparison; curve $c(+-+)$, pretreated 1433 cells added to fresh reaction mixture; curves $d(0 \ldots-0)$, pre-treated 1493 cells added to supernatant fluids from incubation of 1433 or Bact. coli cells with mannitol and phosphate or phosphate only; curves $e(\nabla \ldots . \nabla)$, untreated 1433 cells added to supernatant fluids from incubation of 1433 or Bact. coli cells with mannitol and phosphate or phosphate only,

Pre-treated cells were centrifuged off from their suspending fluid and resuspended in fresh mannitol, phosphate and tetrathionate (Fig. 8, curve c). Apart from some early stimulation of adaptation they were found to be even less active than untreated cells added to the same mixture (Fig. 8, curve $a$ ). When the cells were washed before they were added to the new reaction mixture they showed even less activity.

The loss of activity on transferring pre-treated cells to a new reaction mixture was not due to aeration during the manipulations involved, because when, instead of centrifugation, the mixture was oxygenated at room temperature for 30 min. after pre-treatment, it still showed its full activity on addition of tetrathionate. Nor was it likely to be due to the metabolism of an intermediate, since the activity of pre-treated cells was still lost even if the cells were chilled to $4^{\circ}$ and kept cold during centrifugation and washing. The activity 
lost after centrifugation was, however, fully regained by resuspending the cells in their own supernatant fluid.

The suspending fluid. These observations suggested that some material essential for adaptation was being leached out of the cells by the suspending fluid, and that the inactivation which occurred when the supernatant fluid was discarded was due to loss of this material. The following experiment was performed to investigate the effect of phosphate buffer on the cells.

Two lots of unadapted cells were incubated in $0.2 \mathrm{M}$ buffer for $60 \mathrm{~min}$. and then treated as follows:

(i) Mannitol and tetrathionate were added. It was found that adaptation was slightly less rapid (Fig. 9, curve $b$ ) than that of fresh, untreated, cells put up to adapt in the ordinary way (Fig. 9, curve $a$ ).

(ii) The cells were centrifuged off from the buffer and resuspended in fresh reaction mixture. These cells showed very little activity (Fig. 9, curve c), whereas the buffer in which they had been incubated, when added to untreated cells, stimulated their adaptation (Fig. 9, curve $d$ ).

It can thus be seen that the power of cells to adapt was somewhat damaged by incubation in strong buffer, and also that removal of the buffer deprived the cells of some essential factor which, when added to other cells, stimulated their adaptation.

A further experiment was performed to investigate whether or not this factor was specific to tetrathionate reducing organisms, or connected with the metabolism of mannitol. The following mixtures were made up in duplicate:

$\begin{array}{lcccc} & \text { (i) } & \text { (ii) } & \text { (iii) } & \text { (iv) } \\ \text { Cell suspension of organism } & \text { (ml.) } & \text { (ml.) } & \text { (ml.) } & \text { (ml.) } \\ \begin{array}{l}\text { Bact. coli* cell suspension } \\ \text { Buffer, M }\end{array} & \mathbf{3} & \mathbf{3} & - & - \\ \text { Mannitol, 0.2 M } & \mathbf{3} & - & 3 & 3 \\ \text { Water } & - & 1.5 & - & 3 \\ \text { (m) } & 6 & 6 & 6 & 6\end{array}$

* Bact. coli does not reduce tetrathionate.

These mixtures were incubated at $37^{\circ}$ for $60 \mathrm{~min}$., centrifuged, the cells discarded and the supernatant fluids added to: (A) four lots of packed cells of organism 1433 (from $3 \mathrm{ml}$. of stock suspension) which had been pre-treated with mannitol and buffer for $60 \mathrm{~min}$.; (B) four lots of packed cells each spun off from $3 \mathrm{ml}$. of fresh stock suspension.

The cells were suspended in these fluids and after warming to $37^{\circ}$ the reaction mixtures were completed by the addition of $1.5 \mathrm{ml} .0 .2 \mathrm{M}$ tetrathionate to all tubes and $1.5 \mathrm{ml}$. 0.2 M mannitol to tubes derived from (i) and (iii). Fig. 8, curve $a$ shows a standard (untreated) adaptation and curve $b$ the adaptation of cells after pre-treatment. Curves $d$ show adaptations of pre-treated cells centrifuged off and resuspended in fluids (i)-(iv) as compared with the same cells in a new reaction mixture (curve $c$ ). Curves $e$ show the effect of these fluids on the adaptation of fresh cells as compared with the normal adaptation (curve $a$ ). From these results it can be seen that the activity lost by pretreated cells when separated from their suspending fluid was restored, more 
or less equally, by fluids from reducer or non-reducer cells, with or without mannitol.

The suspending fluids each stimulated the adaptation of fresh cells to a roughly equal extent, but even so, these cells did not adapt so rapidly as the pre-treated cells, suggesting that the chief effect of pre-treatment is to build up intermediates inside the cells.

The cells. The cells themselves were then investigated. It was possible to extract a stimulatory factor from pre-treated cells by centrifuging them after treatment, suspending the deposit in a small volume of water and then placing the suspension in a boiling water-bath for $10 \mathrm{~min}$. The suspension was then cooled, centrifuged and the active extract pipetted off. Some stimulation was given by extracts prepared in the same way from untreated cells and from cells stood in water (at room temperature or at $37^{\circ}$ ) and from cells treated at $87^{\circ}$ in buffer only, but the extract from cells treated with mannitol and phosphate showed greater stimulation. Some of the stimulation of adaptation produced by these extracts might be due to assimilable nitrogen compounds which they contained, but the difference between extracts from untreated and pre-treated cells could only be due to substances produced during pre-treatment.

The stimulatory factor withstood heating at $100^{\circ}$ at $\mathrm{pH} 7 \cdot 3$ for $60 \mathrm{~min}$. When the extract was mixed with four times its own volume of $95 \%(\mathrm{v} / \mathrm{v})$ ethanol a flocculent precipitate appeared (presumably polysaccharide material) and when this was centrifuged off all the activity was found in the ethanolsoluble fraction; the precipitate had no stimulatory effect. When the $\mathrm{pH}$ of the extract was brought to 3.5 a similar precipitate appeared. Again the precipitate was without stimulatory effect, all the activity remaining in the acid-soluble portion. Almost all the active part of the extract passed through a cellophan membrane in 4-5 days when the extract was dialysed against water at $4^{\circ}$. The material inside the sac (which included the presumed polysaccharide substance) was without stimulatory effect. The nitrogen content of the active fraction which passed through cellophan was $0.06 \mathrm{mg}$. N/ml. as compared with $3.8 \mathrm{mg}$. $\mathrm{N} / \mathrm{ml}$. in tryptic heart broth; it seems unlikely therefore that the stimulatory effect was solely due to assimilable nitrogen. The active principle has not so far been identified.

\section{The effect of inhibitors}

2:4-Dinitrophenol at $0.0005 \mathrm{M}$ completely inhibited the adaptation of untreated cells (Fig. 10, curve $c$ ), but when added with the tetrathionate to pretreated cells it did not prevent a slow adaptation (Fig. 10, curve b), suggesting that during pre-treatment there accumulated an intermediate produced at some point subsequent to the dinitrophenol block. Like dinitrophenol, sodium azide at $0.025 \mathrm{M}$ inhibited adaptation, but not reduction of tetrathionate by adapted cells. However, unlike dinitrophenol, azide completely inhibited the adaptation of pre-treated cells (Table 3 ).

From these investigations it seems probable that most of the stimulation of adaptation which occurs when cells are pre-treated in mannitol and phosphate is due to intermediates of mannitol metabolism which accumulate within the 
cells, though material essential for adaptation, and which apparently diffused out of the cells and was independent of the presence of mannitol, did appear in the suspending fluid.

\section{Table 3. Effect of inhibitors on the adaptation of pre-treated cells of organism 1433}

The following mixtures were made up and incubated:

\begin{tabular}{|c|c|c|c|c|}
\hline & \multicolumn{2}{|c|}{$\begin{array}{c}\text { Controls } \\
\text { Tetrathionate and } \\
\text { inhibitor added } \\
\text { at start }\end{array}$} & \multicolumn{2}{|c|}{$\begin{array}{l}\text { Pre-treated cells } \\
\text { Tetrathionate and } \\
\text { inhibitor added } \\
\text { after } 90 \mathrm{~min} .\end{array}$} \\
\hline & (ml.) & (ml.) & (ml.) & (ml.) \\
\hline Stock cell suspension & 2 & 2 & 2 & 2 \\
\hline Buffer, $\mathbf{M}$ & $\mathbf{2}$ & 2 & 2 & $\mathbf{2}$ \\
\hline Mannitol, 0.2 M & 1 & 1 & 1 & 1 \\
\hline Sodium tetrathionate, $0.2 \mathrm{M}$ & $\mathbf{1}$ & $\mathbf{1}$ & $\mathbf{1}$ & 1 \\
\hline Sodium azide, $0.25 \mathrm{M}$ & $\mathbf{1}$ & - & 1 & - \\
\hline 2 :4-Dinitrophenol, 0.01 M & - & $0 \cdot 5$ & - & $0 \cdot 5$ \\
\hline Water & $\mathbf{3}$ & $\mathbf{3} \cdot \mathbf{5}$ & 3 & $3 \cdot 5$ \\
\hline
\end{tabular}

$155 \mathrm{~min}$. after the addition of tetrathionate the tetrathionase activity was measured by the method described

Activity ( $\mu \mathrm{mol}$. thiosulphate produced/mg. dry wt./hr.)

$\overbrace{0.2}^{0.2} \quad 0.2 \quad 1.7$

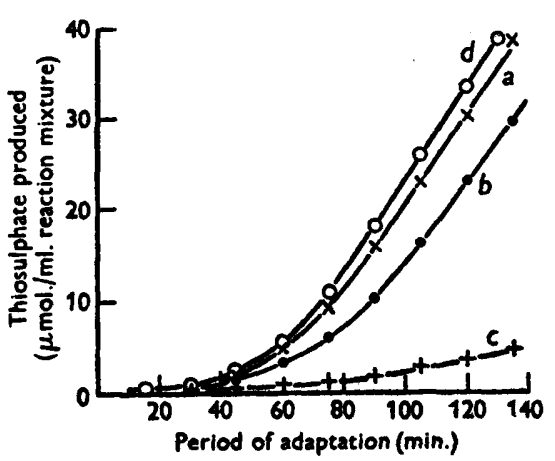

Fig. 9

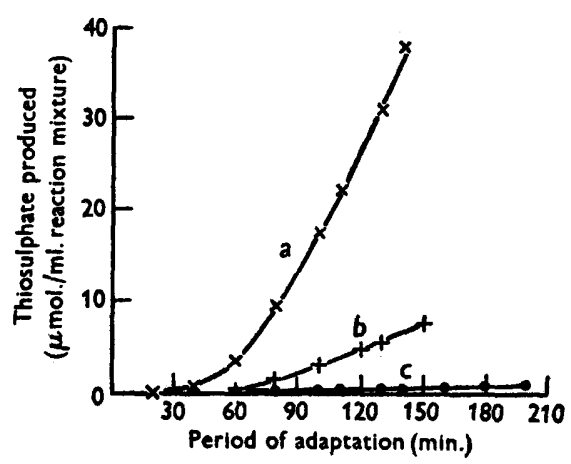

Fig. 10

Fig. 9. Effect of incubation of organism 1433 in $0 \cdot 2 \mathrm{M}$-phosphate buffer $(\mathrm{pH} 7 \cdot 6)$. Curve $a$ $(x-x)$, standard adaptation curve for comparison cells not previously incubated in buffer; curve $b$ (O_- ) , cells incubated in buffer for $60 \mathrm{~min}$., then rest of standard adaptation mixture added; curve $c(+-++)$, cells incubated in buffer for 60 min., centrifuged off from supernatant fluid, and then added to new reaction mixture; curve $d$ $(\mathrm{O}-\mathrm{O})$, supernatant fluid centrifuged off from cells incubated in buffer for $60 \mathrm{~min}$., added to fresh cells and standard adaptation mixture completed.

Fig. 10. Effect of 2:4-dinitrophenol on the adaptation of untreated cells of organism 1433 and on cells pre-treated with mannitol and phosphate. Curve $a(x-x)$, adaptation curve without dinitrophenol for comparison; curve $b(+-+)$, dinitrophenol and sodium tetrathionate added after $90 \mathrm{~min}$. incubation of cells with mannitol and phosphate; curve $c\left(O_{-}\right)$, dinitrophenol and sodium tetrathionate added to untreated cells. 


\section{DISCUSSION}

The results obtained are mostly an amplification of previous work on tetrathionase and a confirmation for this system of conclusions reached with other adaptive enzymes. There are, however, several points worthy of comment. It was observed that the rates of reduction in the presence of dinitrophenol and mannitol, lactate, formate or ethanol, respectively, are in descending order of magnitude (Fig. 3), not only when the cells are fully adapted, but throughout the adaptation, and an unpublished experiment showed that even the small activity of unadapted cells varies with the hydrogen donator used. These observations provide an unexpected example of the dangers (elaborated by Burton, 1936) of thinking in terms of a 'master reaction'-the idea that the overall rate of a process is determined solely by the slowest reaction of the chain. The different rates with different $\mathbf{H}$ donators were first observed with fully adapted cells and it was thought that unadapted cells, which show an overall velocity some forty to fifty times smaller, might reduce tetrathionate at the same rate with all $\mathbf{H}$ donators. But this is not the case. Tetrathionate reduction almost certainly consists of a chain of reactions catalysed by several enzymes, beginning with a dehydrogenase and terminated by an enzyme activating tetrathionate which is the adaptive tetrathionase enzyme. Even when this last is least active and might be expected to be solely responsible for the observed rate, the velocity of reduction is influenced by the specific $\mathbf{H}$ donator used, despite the fact that the slowest of these is not required to supply hydrogen at anything like its maximum rate. Reasonable doubts may be entertained as to the validity of using over-all rates of reduction as a measure of the content of adaptive enzyme, but until cell-free preparations can be obtained there is no alternative.

Monod (1947) observes that most adaptations have the substrate of the adaptive enzyme as the sole metabolite and, therefore, as the only source of energy, so that they might be expected to be in some way autocatalytic, as in fact the course of the adaptation does suggest. Tetrathionase adaptation will occur slowly in washed suspension with lactate as $\mathbf{H}$ donator and also when cells grow anaerobically in tetrathionate lactate medium (Knox et al. 1943). The fact that adaptation occurs so much more rapidly in the presence of a fermentable $\mathbf{H}$ donator would appear to indicate that energy from fermentation can be used for adaptation. The acceleration of adaptation produced by allowing fermentation to begin before adding the tetrathionate is in agreement with this. Further, it seems that in the early stages of adaptation this fermentation energy is either greater in amount, or more available to the adaptive process, than any energy from tetrathionate reduction. The rate of enzyme production does increase with time, for about $60 \mathrm{~min}$., but there is no evidence to show whether or not this is due to more energy becoming available as the rate of tetrathionate reduction increases. It is tempting to suppose that as the rate of reduction increases the metabolism of the carbohydrate becomes oxidative rather than fermentative, with an increase in the available energy.

Adaptation does not occur in the presence of a free supply of oxygen. 
Pollock \& Knox (1943) showed that a free supply of oxygen inhibited tetrathionate reduction by fully adapted cells-this finding is analogous to Stickland's (1981) finding with nitrate-and as it has been shown that oxygenation destroys the tetrathionase of adapted cells it is not surprising that adaptation does not occur in the presence of a free oxygen supply. That the ability to produce new enzyme is not abolished by oxygenation is shown by the fact that adapted cells which have had their tetrathionase destroyed by oxygenation will still adapt, in much the same way as fresh cells, when they are transferred to a suitable environment. Since attempts to re-activate de-adapted cells by incubation with reducing agents were unsuccessful and since the presence of tetrathionate during oxygenation did have some protective effect, it seems possible that the loss of activity is due not to oxidation of some part of the system but rather to reversal of the adaptation process. This de-adaptation produced by exposing the cells to oxygen, the activating enzyme for which is presumably constitutive, appears analogous to the loss of adaptive enzyme attacking certain carbohydrates which occurs when yeast cells are allowed to ferment glueose (Dienert, 1900; Stephenson \& Yudkin, 1936).

To review the evidence for believing that during adaptation an enzymeactivating tetrathionate is synthesized the following may be said: (a) Adaptation occurs without cell division and is not, therefore, a selection of variants. (b) Adaptation is not an increase in the dehydrogenating power of the cells (Pollock, 1946). During adaptation the ability of the cells to ferment mannitol and to take up oxygen in its presence is unchanged, or declines slightly (unpublished observations). (c) Adapted cells, but not unadapted, will activate tetrathionate to oxidize reduced Nile blue (Jebb, 1949). (d) Adaptation is stimulated by the presence of assimilable nitrogen, suggesting a synthesis of nitrogenous material, e.g. protein. (e) Rapid adaptation occurs only in the presence of fermentable carbohydrate, suggesting the need for energy in an anabolic biosynthetic process. $(f)$ 2:4-Dinitrophenol, which stimulates reduction by adapted cells but inhibits adaptation, is known to be an inhibitor of synthetic processes (Reiner, 1946).

Although by no means conclusive, all this evidence is consistent with the view that new enzyme is synthesized in the adaptive process.

\section{REFERENCES}

Burton, A. C. (1936). The basis of the principle of the master reaction in biology. J. cell. comp. Physiol. 9, 1.

Curfton, C. E. (1946). Microbial assimilations. Adv. in Enzym. 6, 269.

Dienert, F. (1900). Sur la fermentation du galactose et sur l'accoutumance des levures a ce sucre. Ann. Inst. Pasteur, 14, 139.

Gare, E. F. (1943). Factors influencing the enzymic activities of bacteria. Bact. Rev. $7,139$.

Gilman, A., Phulups, F. S., Koelle, E. S., Aluen, R. P. \& St John, E. (1946). The metabolic reduction and nephrotoxic action of tetrathionate in relation to a possible interaction with sulphydryl compounds. Amer. J. Physiol. 147, 115.

Gladstone, G. P. \& Findes, P. (1940). A simple culture medium for general use without meat extract or peptone. Brit. J. exp. Path. 21, 161. 
JEBB, W. H. H. (1949). The use of Nile blue in the study of tetrathionase activity. J. gen. Microbiol. 3, 112.

Knox, R., Geul, P. G. H. \& Poulock, M. R. (1943). The selective action of tetrathionate in bacteriological media. J. Hyg., Camb., 43, 147.

Knox, R. \& Pollock, M. R. (1944). Bacterial tetrathionase: adaptation without demonstrable cell growth. Biochem. J. 38, 299.

Kosterurtz, H. W. (1943). The fermentation of galactose and galactose-1-phosphate. Biochem. J. 37, 322.

Monod, J. (1942). Recherches sur la croissance des cultures bactériennes, p. 117. Paris: Herman et Cie.

Monod, J. (1947). The phenomenon of enzymatic adaptation. Grorth, 11, 223.

PoLLOCK, M. R. (1945). The influence of temperature on the adaptation of 'tetrathionase' in washed suspensions of Bact. paratyphosum B. Brit. J. exp. Path. 26, 410.

PoLlock, M. R. (1946). Adaptation of 'nitratase' in washed suspensions of bacteria. Brit. J. exp. Path. 27, 410.

Polnock, M. R. \& Kvox, R. (1943). Bacterial reduction of tetrathionate. Biochem. J. $37,476$.

Pollock, M. R. \& Wainwright, S. D. (1948). The relationship between nitratase and tetrathionase adaptation and cell growth. Brit. J. exp. Path. 29, 223.

Reiner, J. M. (1946). The effect of enzyme inhibitors on transformation of enzymes in the living cell. Proc. Soc. exp. Biol., N.Y., 63, 81.

Ronzon, E. \& Ehrenfest, E. (1936). The effect of dinitro-phenol in the metabolism of frog muscle. J. biol. Chem. 115, 749.

SPIEgELMaN, S. (1945). The physiology and genetic significance of enzymatic adaptation. Ann. Mo. bot. Gdn, 32, 139.

SpIEgelman, S., Reiner, J. M. \& Morgan, I. (1947). The apo-enzymatic nature of adaptation of galactose fermentation. Arch. Biochem. 13, 113.

Stephenson, M. \& Yudkin, J. (1936). Galactozymase considered as an adaptive enzyme. Biochem. J. 30, 506.

STICKLAND, L. H. (1981). The reduction of nitrates by Bact. coli. Biochem. J. 25, 1543.

Wrukinson, J. F. (1949). The pathway of adaptive fermentation of galactose by yeast. Biochem. J. 44, 460 . 